\title{
Andrzej Gielarowski
}

\section{Transcendencja, immanencja, tajemnica. Figury niewidzialności Boga we współczesnej fenomenologii religii}

\author{
Transcendence, Immanence, Mystery: \\ The Figures of God's Invisibility in the \\ Contemporary Phenomenology of Religion
}

\section{Abstrakt}

Artykuł podejmuje tematykę nieanalizowaną dotychczas w polskiej literaturze filozoficzno-religioznawczej, która dotyczy niepoznawalności lub niewidzialności Boga we współczesnej francuskiej fenomenologii religii, traktowanej jako nurt badań (filozoficznych i religioznawczych), w którym ta tematyka znajduje odzwierciedlenie. Autor skupia się na pojęciach transcendencji, immanencji i tajemnicy wypracowanych odpowiednio przez Emmanuela Lévinasa, Michela Henry'ego oraz przez Gabriela Marcela. Dyskusja nad tymi trzema koncepcjami ukazuje, iż transcendencja (Lévinas) i immanencja (Henry) są pojęciami, które jednostronnie realizują zadanie, jakie postawili przed nimi ich autorzy, to znaczy dążenie do "uchronienia" Boga przed uprzedmiotowieniem, do którego prowadzi nieuchronnie metoda fenomenologiczna, zwłaszcza w wersji przedstawionej przez Edmunda Husserla. W opozycji do tej metody pozostają nie tylko Lévinas 
i Henry, ale także Marcel, który zastosował w celu "uchronienia" Boga od uprzedmiotowienia przez obiektywizujące poznanie intelektualne, pojęcie tajemnicy. Według autora artykułu, to właśnie tajemnica (Marcel), a nie transcendencja (Lévinas) czy immanencja (Henry), jest pojęciem, które, użyte do fenomenologicznego opisu Boga, skutecznie "broni” Go przed uprzedmiotowieniem. Z punktu widzenia fenomenologii religii istotne jest to, że w myśli Marcela Bóg nie ukazuje się jako fenomen (jak uważali także Gerardus van der Leeuw oraz Lévinas i Henry), ale mimo to możliwa jest relacja religijna między człowiekiem a Bogiem, której wyrazem jest modlitwa. Ta rozumiana biblijnie relacja nie może zaistnieć w myśli Lévinasa czy Henry'ego, mimo że ich koncepcje również mają dość silne zakorzenienie w Biblii. Dlatego autor tekstu uważa, że Marcelowska koncepcja tajemnicy lepiej odpowiada oczekiwaniom człowieka wierzącego (homo religiosus) niż koncepcje transcendencji i immanencji odniesione do Boga. Wypracowana przez Gabriela Marcela koncepcja Boga jako Tajemnicy pozwala bowiem na wejście z Nim w relację religijną dzięki kierowanej ku Niemu modlitwie.

Słowa klucze: Bóg, fenomenologia, Henry, Lévinas, Marcel, modlitwa, nieobecność, niepoznawalność, obecność, religia, życie

\section{Abstract}

The article addresses the problem, which has not yet been analyzed in the Polish philosophical and anthropological literature, and which deals with the subject of unknowability or invisibility of God in the contemporary French phenomenology of religion. The text focuses on the ideas of transcendence, immanence and mystery as developed and further elucidated by Emmanuel Lévinas, Michel Henry and Gabriel Marcel. The author deduces from the philosophical discourse on the three concepts that the transcendence (as understood by Lèvinas) and immanence (as perceived by Henry) are the ideas which unilaterally carry out the tasks set for them by their authors, which is "to protect" God from objectification to which the phenomenological method leads when applied to the problem at stake, in particular, as it was presented by Edmund Husserl. Not only Lévinas and Henry were in opposition to this method but so was Marcel. who had used the concept of mystery for the same reason. According to the author of the article, neither the transcendence (Lévinas) nor the immanence (Henry) but the concept of mystery (as developed by Marcel) is the one which "protects» God the most efficiently against objectification. From the phenomenology of religion point of view the most important thing is that in Marcel's thought God does not appear as a phenomenon (as Gerardus van der Leeuw and Lévinas and Henry believed), and yet that does not exclude the religious relationship between Man and God. 
According to Lévinas and Henry this biblically understood relation cannot exist even though their concepts also have relatively strong foundations in the Bible. Therefore, the author of the text believes that the Marcelian concept of mystery meets the expectations of a believer (homo religiosus) better than the Lévinasian concept of transcendence and the Henrian idea of immanence. The concept of God as the Mystery as developed by Gabriel Marcel allows man to enter into a religious relationship with God by the means of prayer.

Keywords: God, phenomenology, Michel Henry, Emmanuel Lévinas, Gabriel Marcel, prayer, invisibility, unknowability, appearance, religion, life

\section{Wprowadzenie}

Współczesna fenomenologia religii tworzy dwa nurty: „filozoficzny”, kontynuujący teoretyczne nastawienie fenomenologii Edmunda Husserla, i „religioznawczy”, w którym znaczną rolę, obok metody fenomenologicznej, odgrywają badania historyczne nad religią. W obu nurtach pojawia się jednak pytanie o rodzaje przystępu do Boga, teoretyczne bądź praktyczne'. W wyniku tych badań niektórzy z fenomenologów religii, na przykład Gerardus van der Leeuw, dochodzą do wniosku, że „W fenomenologii Bóg nie jest ani podmiotem, ani przedmiotem, albowiem musiałby być fenomenem, tj. musiałby ukazywać się. Bóg zaś nie ukazuje się, tj. nie ukazuje się w taki sposób, żebyśmy mogli go rozumieć i mówić o nim”2. Przekonanie van der Leeuwa o niepoznawalności Boga, jest bliskie tym fenomenologom religii, którzy nawiązując krytycznie do Husserla, rozwijają intuicje wyrażone przez holenderskiego religioznawcę. Do tych fenomenologów należą m.in. Emmanuel Lévinas i Michel Henry, ale też Gabriel Marcel ${ }^{3}$, których koncepcje zarysuję analizując kwestię niewidzialności (niepoznawalności) Boga we francuskiej

1 Richard Schaeffler, Filozofia religii, tłum. Elżbieta Kowalska (Częstochowa: Częstochowskie Wydawnictwo Diecezjalne Regina Poloniae, 1989), 85-112; Jean Greisch, Le buisson ardent et les lumières de la raison. Linvention de la philosophie de la religion, t. II: Les approches phénoménologique et analytiques (Paris: Cerf, 2002), 17-372. Cytowani autorzy uważają fenomenologię religii, rozwijaną w nurtach umownie zwanych tu „filozoficznym” i „religioznawczym”, za jeden współczesny nurt filozofii religii.

2 Gerardus van der Leeuw, Fenomenologia religii, tłum. Jerzy Prokopiuk (Warszawa: Książka i Wiedza, 1997), 597.

3 O „fenomenologii złamanej” Marcela pisze Karol Tarnowski, „Intencja a refleksja. Fenomenologia, Nabert, Marcel”, w Między przedmiotowościa a podmiotowością: intencjonalność w fenomenologii francuskiej / Entre l'objectivité et la subjectivité: 
fenomenologii religii. Postaram się pokazać, iż ani absolutna transcendencja Boga (Lévinas), ani radykalna immanencja życia utożsamionego z Bogiem (Henry) nie opisują właściwie boskiej niewidzialności, którą ci filozofowie postulują. Zarówno radykalna transcendencja, jak i absolutna immanencja zwiększają bowiem dystans między człowiekiem religijnym (homo religiosus) a Bogiem, jeśli całkowicie nie wykluczają relacji religijnej. Postaram się także wykazać, że to tajemnica, jako wypracowany przez Marcela sposób rozumienia niewidzialności Boga, zarazem przyznaje istotne znaczenie boskiej niewidzialności, jak też czyni możliwym praktyczny dostęp do Boga, głównie przez modlitwę opartą na wierze, oraz przez dialogiczną relację z drugim człowiekiem, opisywaną jako wspólnota bycia. Uznanie tajemnicy za adekwatny fenomenologicznie sposób opisu boskiej niewidzialności pozwala uniknąć trudności wynikających ze stanowisk Lévinasa i Henry'ego, a zarazem umożliwia zrealizowanie dążeń tych filozofów, którzy pragnęli uniknąć tworzenia idoli boskości, powstających przy próbach poznawczego ujęcia Boga.

Dlaczego w myśli trzech francuskich fenomenologów pojawia się krytyka poznawczej idolatrii, której należy, według nich, unikać? Wedle Husserla żaden przedmiot poznania nie może być poznawczo dany inaczej niż jako oczywistość osiągnięta w intuicji, stanowiącej świadomościowe widzenia tego, co dane w sposób źródłowy. Zadaniem fenomenologa jest opis tego, co „widzi”, co jest mu dostępne w akcie świadomości intencjonalnej, która zwraca się na zewnątrz siebie oraz na swe przeżycia. Husserl utożsamia "sens” (niem. Sinn), jawiący się w świadomości jako fenomen, z „bytem” (niem. Sein), dlatego byt, w jego ujęciu, konstytuowany jest przez świadomość jako sens obiektywny rzeczy. To, co dane w intuicji, jest więc zawsze „widziane” i „obecne” dla świadomości, czyli poznawczo zobiektywizowane. Intuicja bowiem jest formą obiektywizacji ${ }^{4}$. Czy ta metoda stosuje się także do poznania Boga? Bez względu na wielość interpretacji, niekiedy wzajemnie się wykluczających, dotyczących kwestii Boga w myśli twórcy fenomenologii, należy wskazać to ujęcie kwestii przez Husserla, które pozwala zrozumieć protest Lévinasa, Henry’ego czy Marcela, zwrócony - świadomie lub nie - przeciw poznawczemu uprzedmiotowieniu Boga.

l'intentionnalité dans la phénoménologie française, red. Andrzej Gielarowski, Robert Grzywacz (Kraków: Akademia Ignatianum-Wydawnictwo WAM, 2011), 28.

4 Walter Biemel, „L'idée de la phénoménologie chez Husserl” w: Phénoménologie et métaphysique, red. Jean-Luc Marion i Guy Planty-Bonjour (Paris: PUF, 1984), 81-104. Denise Souche-Dagues, Le développement de l'intentionnalité dans la phénoménologie husserlienne (Paris: Vrin, 1993), 22-25. 
Fenomenologii Husserla stawiano zarówno zarzuty przesadnej obiektywizacji, jak też zbytniej immanentyzacji poznawczej ${ }^{5}$. Wydaje się, że zarzut obiektywizacji wobec myśli fenomenologicznej ma pewien wspólny mianownik. Jest ona bowiem zawsze związana z intencjonalnością, która uprzedmiotawia to, co poznawane. Husserl wyróżnia różne przedmioty poznania, zawsze ujmowane przez rozum i jemu poddane: przez redukcje transcendencji do immanencji (jak chce Lévinas) lub przez „uzewnętrznienie" immanencji (jak sądzi Henry). W obu przypadkach świadomość intencjonalna poddaje sobie rzeczywistość niewidzialną, która nie powinna być sprowadzana do tego, czym nie jest, i nie powinna być poddana świadomości, ustanawiającej „widzialność” tego, co poznaje. Jeśli wobec Boga stosuje się tę samą procedurę poznania fenomenologicznego, to, wedle przywołanych francuskich myślicieli, w wyniku tego tworzy się idola. W tym względzie jednak Husserl nie jest jednoznaczny, gdyż, jak uważa jeden $\mathrm{z}$ komentatorów tej kwestii, w jego badaniach Bóg zajmuje miejsce marginalne. Jednak nie da się zaprzeczyć, że w badaniach tych Bóg musi być poddany świadomości intencjonalnej, nawet jeśli ją niekiedy przekracza ${ }^{6}$. Jeśli więc fenomenologia Husserla nie wyklucza w ogóle Boga ze swych badań, traktując Go jako „absolutny transcendens”, to na pewno redukuje Go do treści świadomości, poddając poznawczemu rozumowi ${ }^{8}$. Z protestu względem tej redukcji wyrastają koncepcje niewidzialności Boga, które omówię.

\section{Transcendencja Boga, aż po nieobecność: Lévinas}

Emmanuel Lévinas pokazuje, że pojęcie transcendencji jest fundamentalne dla każdej myśli, która nie chce być winna fałszowania obrazu Boga przez tworzenie idoli na miarę rozumu. Transcendencja jest imieniem Boga, który nie jest ani „Bogiem filozofów”, ani „Bogiem wiary”. Opozycja ta zostaje przez Lévinasa zakwestionowana, gdyż Bóg nie jest obecnością, do której można się odnosić w jakikolwiek sposób. Autor Inaczej niż być... ujmuje bowiem obecność jako reprezentację?. To w relacji

5 Greisch, Le buisson ardent et les lumières de la raison, 60-66.

6 Witold Płotka, Fenomenologia jako filozofia mniejsza. Rozważania wokół sporów o metode Husserla (Warszawa: Liberlibri, 2019), 135-139, 150-153.

7 Karol Tarnowski, Bóg fenomenologów (Tarnów: Biblos, 2000), 254.

8 Halina Perkowska, Bóg filozofów XX wieku. Wybrane koncepcje (Warszawa-Poznań: Wydawnictwo Naukowe PWN, 2001), 173.

9 Emmanuel Lévinas, O Bogu, który nawiedza myśl, tłum. Małgorzata Kowalska (Kraków: Wyd. Znak, 1994), 116; idem, Bóg, śmierć i czas, tłum. Janusz Margański (Kraków: Wyd. Znak, 2008), 154. 
do tak pojętej obecności Bóg jest „transcendentny aż do nieobecności”"10. Lévinas stara się boskość „odesłać” poza horyzont poznawczy człowieka, który wyznacza immanencja redukująca wszelką transcendencję, każdą - nieredukowalną z istoty wedle filozofa - inność Innego (Boga i człowieka). To przekonanie potwierdzają, wedle niego, dzieje zachodniej filozofii. Pisze on bowiem: „To nie przypadek, że historia zachodniej filozofii jest historią niszczenia transcendencji"”l. Gdy Lévinas mówi więc o przeciwieństwie transcendencji, jakim jest immanencja, to ma na uwadze immanencję poznawczą, wynikającą z totalizującej (scalającej) działalności rozumu. Dobrze ujmuje tę skłonność ludzkiej świadomości, obecną u Husserla i odniesioną do Boga, komentarz, w którym czytamy: „Poznawczy rozum jako kwintesencja świadomości [transcendentalnej AG], nie pozostawiając niczego na zewnątrz siebie, a mówiąc dokładniej, tworząc dopiero sens podziału na zewnętrzność i wewnętrzność, musi również Boga rozpoznawać jako jedno z własnych ukonstytuowań" ${ }^{12}$. Transcendencja jest więc tym, co tak rozumianej totalizacji dokonywanej przez rozum wymyka się z istoty.

Broniąc boskości przed poznawczym zawłaszczaniem przez immanencję świadomości, Lévinas pojmuje transcendencję jako niepoddającą się żadnej formie obiektywizacji. Nie można więc myśleć o transcendencji jako związanej z wykraczaniem intencji w kierunku przedmiotu, bowiem akt intencjonalności transcendującej świadomość jest odmianą redukcji, której świadomość dokonuje wobec rzeczywistości. Transcendencja wykracza więc poza immanencję myśli i wymyka się poznaniu intencjonalnemu. Chodzi tu o transcendencję, która byłaby „transcendencją nie poznawczą, lecz para-doksalną "13, niemogącą znaleźć spełnienia w wiedzy, w doxa, lecz posiadającą sens, „który nie jest poznawczą tezą"14. Dla Lévinasa modelem transcendencji jest Kartezjańska idea nieskończoności, która „nawiedza myśl”, lecz w której sama Nieskończoność nie pozwala się uchwycić i zobiektywizować poznawczo. Transcendencja jest pewną enigmą, dającą o sobie znać przez ślad znaczący twarz drugiego człowieka. Filozof, komentując rozumienie transcendencji, pisze: „Istniałby więc paradoksalny sposób przejścia od transcendencji Husserlowskiej, która pozostaje immanencją, do transcendencji wychylonej ku Innemu. Inny, który jest niewidzialny i od którego nie oczekuje się

10 Idem, Bóg, śmierć i czas, 270.

11 Idem, O Bogu, który nawiedza myśl, 115.

12 Perkowska, Bóg filozofów XX wieku, 173.

13 Lévinas, Bóg, śmierć $i$ czas, 161.

14 Ibidem, 150. 
żadnego spełnienia, byłby nieobejmowany, nietematyzowalny"15. Ostatecznie liczy się, jak pisze Lévinas, „Nieskończona transcendencja, albowiem idea wypełnienia celu przez widzenie pozostaje tutaj poza kwestią, poza miarą. Transcendencja niewspółmierna. Oznacza to, że chodzi tutaj o coś innego niż intencjonalność” ${ }^{\prime 1}$. Nie można więc mówić o transcendencji drugiego człowieka czy Boga, zamykając ich w poznawczym horyzoncie, ograniczonym przez intencjonalność, nawet rozumianą jako wykraczanie świadomości poza siebie. Zawsze bowiem ma ona tendencję do obiektywizowania, lub, jak wyraża to filozof, do zawłaszczania czy redukowania swego przedmiotu do siebie, pozbawiając go inności.

Dlatego w myśli Lévinasa mamy do czynienia z poszukiwaniem relacji, która nie redukowałaby transcendencji Innego (człowieka i Boga) do świadomości poznającej. Filozof odchodzi więc od rozumienia transcendencji w kategoriach Husserlowskiej intencjonalności na rzecz relacji, która ma inny charakter niż poznawczy czy teoretyczny. W istocie chodzi o relację etyczną, polegającą na odpowiedzialności za innego człowieka, która nie jest poznaniem i należy do praktycznego porządku etyki. „Transcendowanie w nieskończoność na podstawie odpowiedzialności za bliźniego, w bliskości drugiego człowieka - wyjaśnia fenomenolog oznacza tutaj, na ziemi, znaczeniowość bez widzenia czy nawet intencji”'17. Bowiem idea nieskończoności, która jest modelem transcendencji dla Lévinasa, to, jak zaznacza, „myślenie bardziej refleksyjne niż poznawanie: sposób, w jaki nieskończony może znaczyć, nie tracąc swojego transcendentnego znaczenia"18. Dzięki tej idei możemy, jego zdaniem, myśleć relację z czymś, co nas przekracza jako nieogarnione i „rozbija” podmiotową tożsamość, którą rozumie filozof jako immanencję redukującą to, co poznawane do siebie. „Idea nieskończonego - pisze Lévinas - mieści się $w$ myśleniu, lecz owo $w$ rozsadza tożsamość" ${ }^{\prime 19}$. Należy tę ideę badać jako podjęcie odpowiedzialności za innego człowieka. Odtąd, „podmiotowość nie jest sprowadzalna do podmiotu intencjonalnego, lecz w formie przebudzenia wyraża znaczenie, które byłoby lepsze niż bycie, które byłoby samym Dobrem"20. Podmiotowość ma bowiem, w tej myśli, charakter ściśle etyczny. Jest to „zakładnik”, którego tożsamość „jest implikowana w intrydze bliskości jako dostęp do bliźniego. Dostęp paradoksalny,

\footnotetext{
15 Ibidem, 161.

16 Ibidem.

17 Ibidem, 168.

18 Ibidem.

19 Ibidem, 171.

20 Ibidem, 172.
} 
ponieważ wraz z nim w miarę zbliżania się dystans się zwiększa i im jest się blizzej, tym dalej. Ów paradoks jednak wpisuje chwałę Nieskończonego w relację zwykle nazywaną intersubiektywnością. $Z$ tej relacji w chwale unosi się Nieskończony"21. Drugi człowiek jest wszak tym, do kogo nas odsyła Bóg, Nieskończony, który jest transcendentny tak radykalnie, że aż nieobecny. Bóg daje więc znać o sobie tylko w relacji etycznej z drugim człowiekiem, za którego jestem odpowiedzialny i do którego jestem posłany, aby mu służyć. Innej możliwości dostępu do Boga Lévinas nie ukazuje.

Najistotniejszy sens transcendencji, jaki znajdujemy u Lévinasa, związany jest więc z radyklaną nieobecnością Boga i ze „skierowaniem” zwróconego do Boga ludzkiego pragnienia w stronę drugiego człowieka, bliźniego, którego bynajmniej nie pragnę. Jak wyjaśnia filozof: „Ażeby w pragnieniu była możliwa bez-inter-esse-owność, ażeby pragnienie poza byciem nie było pochłanianiem, to, co upragnione (albo Bóg) musi zostać w pragnieniu odseparowane: bliski, lecz różny - taki skądinąd sens ma słowo «święty». Możliwe jest to tylko wtedy, gdy upragniony poleca mnie temu, co niepożądane par excellence: drugiemu człowiekowi”22. Gdy Bóg odsyła mnie do drugiego człowieka, to odwołuje się do mojej odpowiedzialności za niego, która obliguje mnie i wiąże z nim, aż po wymóg substytucji za niego, po oddanie życia oraz aż po wzięcie odpowiedzialności za zło popełnione przez niego ${ }^{23}$. Transcendencja, o której mowa, realizuje się bowiem przede wszystkim w odpowiedzialności za bliźniego, z którym relacja „zastępuje” niemożliwą relację z Bogiem, tak radykalnie transcendentnym, że aż nieobecnym. Tylko tak rozumiana transcendencja, Boga i drugiego człowieka, może pozwolić uniknąć wszelkiej idolatrii wynikającej z prób poznawczego ich ujęcia.

Nieskończony, Bóg, w późnej myśli Lévinasa, na której tu się skupiłem, nie jest więc dostępny ani w drodze poznania, ani na innych drogach niż poznanie. Nie jest bowiem możliwe także dosięgnięcie Go na drodze pragnienia. Dzięki odwróceniu pragnienia, Upragniony, czyli Bóg, wymyka się bowiem memu pragnieniu, które ma wszak pewną intencję. „Dobroć Dobra - pisze Lévinas - nachyla ruch, do którego ona odwołuje się, żeby odsunąć Dobro jako upragnione i skierować je ku Drugiemu Człowiekowi - a tym samym tylko ku Dobru”24. Upragniony Bóg pozostaje więc nieobecny, dlatego określany jest przez filozofa jako „On”

21 Ibidem, 193.

22 Ibidem, 268.

23 Lévinas, O Bogu, który nawiedza myśl, 150; idem, Bóg, śmierć i czas, 268.

24 Idem, Bóg, śmierć i czas, 269. 
lub „Oność”. W odesłaniu od Upragnionego (Boga) do nieupragnionego (człowieka), które mi nakazuje zbliżenie się do drugiego człowieka, jak wyraża się autor Inaczej niż być..., „Bóg zostaje wyrwany obiektywności obecności i byciu. Nie jest już ani przedmiotem, ani rozmówcą w dialogu. Jego oddalenie się czy jego transcendowanie obracają się w moją odpowiedzialność: nieerotyczność par excellence!"25. Więź religijna z Bogiem zostaje więc zastąpiona całkowicie przez etyczną relację z drugim człowiekiem. Transcendencja Boga, a wraz z nią niewidzialność boskości, $\mathrm{w}$ istocie jest więc absolutna i niepodważalna. Istnieje bowiem jedynie możliwość służby drugiemu człowiekowi, który jest tym, wobec kogo winienem zwracać się z troską o konkretne jego potrzeby i do kogo nie mogę przychodzić z pustymi rękami ${ }^{26}$. Transcendencja (niewidzialność) Boga staje się więc, w myśli filozofa, całkowitą nieobecnością, poznawczą, jak też każdą inną. Nie można $z$ tak pojętym Bogiem nawiązać jakiejkolwiek relacji religijnej. Chociaż służba bliźniemu ma pełnić funkcję takiej relacji, to raczej zastępuje ona wszelką relację człowieka z Bogiem, wykluczając ją i ograniczając się do relacji z drugim człowiekiem.

\section{Immanencja Życia absolutnego aż po niewidzialność: Henry}

Michel Henry, tak jak Lévinas, uznaje oddzielenie tego, co widzialne, co poddaje się procedurom poznawczym, od sfery niewidzialnego, która nie może być ujęta przez rozum. Sferą niewidzialności, wiązaną od razu $\mathrm{z}$ niewidzialnością Boga, tożsamego $\mathrm{z}$ absolutnym Życiem ${ }^{27}$, jest immanencja, w której wszak nie wolno widzieć wymiaru świadomości, gdyż przynależy ona ludzkiej cielesności (fr. chair) ${ }^{28}$. Intencjonalna, zgodnie z tezami fenomenologii Husserla, świadomość, jest, jak pisze Henry, „ruchem, poprzez który wyrzuca ona siebie na zewnętrz, jej «substancja»

25 Ibidem.

26 Emmanuel Lévinas, Imiona własne, tłum. Janusz Margański (Warszawa: Wyd. KR, 2000), 43.

27 We wczesnych pracach Michel Henry - Lessence de la manifestation (Paris: PUF, 2003), 385-571 - utożsamiał życie z Bogiem bez wprowadzania rozróżnień między tymi pojęciami. Dopiero w jednej ze swych późnych prac wprowadził wyraźne odróżnienie życia od Życia absolutnego. Odróżnia więc, także w pisowni, „Życie” tożsame z Bogiem od „życia” tożsamego z życiem ludzkim lub tym, które nie zostało wyraźnie określone jako pierwsze lub drugie. Michel Henry, C'est Moi la Vérité. Pour une philosophie du christianisme (Paris: Seuil, 1996), 40.

28 Michel Henry, Wcielenie. Filozofia ciała, tłum. Dariusz Adamski, Małgorzata Frankiewicz (Kraków: Homini, 2012), 31, gdzie autor wyjaśnia odróżnienie dwóch sensów ciała ludzkiego: ciała-przedmiotu (fr. corps) i ciała żywego lub cielesności (fr. chair). 
wyczerpuje się w tym wyjściu na zewnątrz, które tworzy zjawiskowość"29. Zewnętrzny wobec podmiotowości - którą stanowi ostatecznie cielesność (chair) - świat jest „ekstatycznym horyzontem widzialności, w obrębie którego każda rzecz może stać się widoczna"30. Poznanie wyłaniające się z zewnętrzności świata, tj. poznanie intencjonalne lub naukowe, od razu staje się poznaniem ogólnym. Autor Wcielenia podkreśla, że poznanie polegające na ukazywaniu się w świecie, obiektywizacja, odwodzi człowieka od jego najbardziej własnej istoty. Zakłada ono bowiem wrzucenie w świat lub, jak pisze Henry, „wypędzenie” poznającego z jego „Domostwa”, z „pierwotnej Ojczyzny” ${ }^{31}$, którą jest wszak immanencja podmiotowości, czyli jej cielesność (chair).

Jest tak dlatego, iż transcendencja jako czasowość i ukazywanie się w zewnętrzności świata jest środowiskiem irrealności, absolutnej iluzji. Właściwym środowiskiem egzystencji podmiotu jest natomiast niewidzialność immanencji, której nigdy nie opuszczamy i dlatego możemy ją utożsamić z wieczną teraźniejszością. Podmiotowość czy Sobość (fr. Soi) jest pozaświatowa i obca określeniom pochodzącym ze świata rozumianego jako zewnętrzność, który jest tożsamy z horyzontem widzialności i obiektywności ${ }^{32}$. Sobość rodzi się z absolutnego Życia albo raczej rodzi się w przychodzeniu do siebie, w samoobjawianiu się, tego Życia, które filozof utożsamia z Bogiem. Pisze bowiem: „Ja sam jestem tą niepowtarzalną Sobością, zrodzoną w somorodzeniu się absolutnego życia i jestem tylko tym. Życie samo rodzi siebie jako mnie samego. Moje transcendentalne narodziny to powstawanie w samorodzeniu się absolutnego życia niepowtarzalnej Sobości, którą ja sam jestem" ${ }^{33}$. To w życiu, które samo „zradza mnie jako samo siebie” ${ }^{34}$, jestem w pełni sobą, gdyż immanencja życia, a nie transcendencja świata jest „żywiołem” i „siedzibą” podmiotowości.

Zrodzeni w życiu, nie jesteśmy więc mieszkańcami świata, gdy przez świat rozumiemy zewnętrzność określoną przez obiektywizującą świadomość intencjonalną. Życie bowiem jest niewidzialne i pozostaje zawsze w swej immanencji. Nie ma ono „zewnętrznej strony”, która mogłaby zostać ukazana w świetle horyzontu świata. Jak pisze Henry:

29 Michel Henry, O fenomenologii, tłum. M. Drwięga (Warszawa: Wydawnictwo IFiS PAN, 2007), 93.

30 Ibidem, 94.

31 Ibidem, 94-95.

32 Michel Henry, Entretiens (Cabris: Sulliver, 2007), 11-12.

33 Idem, O fenomenologii, 176.

34 Ibidem, 176. 
„Nikt nigdy nie widział życia i nikt go nigdy nie zobaczy. Życie jest wymiarem radykalnej immanencji. Jeśli możemy pomyśleć immanencję, to oznacza ona wykluczenie wszelkiej zewnętrzności, nieobecność tego transcendentalnego horyzontu widzialności, w którym każda rzecz może stać się widzialna, a który nazywamy światem" ${ }^{35}$. Tak pojęte życie, rozumiane od początku jako powiązane ściśle z Życiem absolutnym, jest przez Henry’ego utożsamione z Bogiem. Absolutnemu Życiu, swe konkretne życie zawdzięczają poszczególne żywe Sobości. „Ja jestem sobą samym - pisze myśliciel - ale nie przyniosłem mnie samego do tego ja, którym jestem. Jestem dany mnie samemu, ale to nie ja dałem mnie sobie samemu. Jestem dany mnie samemu, moje życie jest dane sobie w tej Sobości, którą jestem tylko w samodonacji absolutnego Życia w jego Słowie" ${ }^{36}$. Bowiem Życie nieskończone, absolutne, objawiając się, rodzi Pierwszą Żyjącą Sobość (fr. Ipséité), w której każdy człowiek jest Synem Życia czy, jak doprecyzowuje filozof, Synem w Synu, czyli Synem Bożym w Chrystusie ${ }^{37}$. To ujęcie ma podstawę w fenomenologii życia, rozwijanej przez Henry'ego i przez chrześcijaństwo. Fenomenologia ta głosi, iż „Życie ma ten sam sens dla Boga, dla Chrystusa i dla człowieka, a to dlatego, iż jest tylko jedna i ta sama istota Życia lub bardziej radyklanie to ujmując, jedno jedyne Życie" ${ }^{38}$.

Mimo formalnej różnicy, istnieje ścisła tożsamość ludzkiego i boskiego Życia. Nasza Sobość, jako tożsamość (Ipséité) Syna Życia, odsyła więc do Pierwszej Żyjącej Sobości, gdyż nikt nie może sam sobie dawać siebie, czyli siebie zrodzić. Nasze życie jest więc nam darowane, a zarazem jest ono poddane Życiu absolutnemu, z którego czerpie konkretne określenia, takie jak radość i cierpienie, przeżywane w cielesności (chair). Skończone życie człowieka „czerpie swoją możliwość z arcypodległości Życia nieskończonego" ${ }^{39}$, co oznacza pasywność, poddanie absolutnemu Życiu. W tym kontekście obiektywne ciało przedmiotowe (corps) staje się wtórne wobec ciała żywego, cielesności (chair), która, tak jak życie, nie potrzebuje określeń czy racji pochodzących z zewnętrz, z obiektywnego świata, w którym zakorzenione jest ciało-przedmiot (corps). W jedności samoodczuwania się Życia absolutnego w skończonym życiu cielesności (chair), widzi Henry tożsamość ludzkiej podmiotowości z Bogiem ${ }^{40}$.

35 Ibidem, 79.

36 Ibidem, 101-102.

37 Idem, Cest Moi la Vérité, 120-167.

38 Ibidem, 128 (kursywa w tekście oryginalnym).

39 Idem, O fenomenologii, 109.

40 Ibidem, 111. 
To możliwe, gdyż, jak twierdzi filozof powołując się na Mistrza Eckharta, "Istotą życia jest Bóg”"11. A skoro my także jesteśmy żyjącymi, więc nosimy w sobie tę samą istotę życia, którym żyje i którym jest Bóg. Podkreśla to Henry odwołując się znów do słów Eckharta, który twierdził nawet, iż "Istotą Boga jest moje życie"

Bóg, jeśli jest tożsamy z niepoznawalnym w horyzoncie świata życiem, nie może być w żaden sposób dostępny intencjonalnie. Tożsamość życia podmiotowości i życia boskiego sprawia, że jedyny sposób dostępu do Boga zależy od tego, jak objawia się życie. Ono zaś doznaje siebie bezpośrednio, czyli jest pasywne wobec siebie, tzn. nie podlega dystansowi związanemu z poznaniem w horyzoncie zewnętrzności, w transcendencji świata określonej przez czas. W wewnętrznej istocie życia nie ma nic, co może być poddane obiektywizacji. Życie doświadcza siebie poza światem i nie poddaje się poznaniu rozumowemu związanemu z intencjonalnością. Stąd możemy mówić o aksomiczności oraz wieczności nie tylko boskiego, ale także ludzkiego życia ${ }^{43}$. Henry nie waha się stwierdzić: „Ponieważ Bóg jest Życiem, to w konsekwencji trzeba wraz z Mistrzem Eckhartem stwierdzić, że «Bóg rodzi mnie jako siebie i siebie jako mnie» (...)"44. Jedność tego, co boskie, i tego, co ludzkie w immanencji życia, jest nierozerwalna. Bóg, Życie absolutne, jest immanentny wobec człowieka jako źródło życia, ale zarazem jest radykalnie pozaświatowy i niedostępny dla obiektywizującego poznania intencjonalnego. Bóg jest bowiem niepoznawalnym fundamentem podmiotowości a zarazem całej ludzkiej rzeczywistości.

Można więc stwierdzić, iż w myśli Henry’ego nie ma innej drogi do Boga, czy innego miejsca Jego objawienia się człowiekowi, jak tylko immanentne życie ludzkie tożsame z przychodzeniem tego życia do siebie i zanurzonego w Życiu absolutnym, co realizuje się w ludzkiej cielesności (chair). Jednak manifestacja życia, a z nią objawienie Boga, z istoty różni się od jawienia się w świecie. Pisze wszak Henry, iż „(...) decydującą cecha objawiania życia jest to, że ono, które nie nosi w sobie żadnego odstępu i nie różni się nigdy od siebie, zawsze objawia tylko siebie samo. Życie objawia siebie. Życie jest samoobjawianiem. Z jednej strony, życie dokonując dzieła objawienia, jest ono wszystkim tylko nie ślepą istotą (entité aveugle), z drugiej tym, co ono objawia, jest ono samo.

41 Michel Henry, „Acheminement vers la question de Dieu”, w Michel Henry, Phénoménologie de la vie, t. IV, Sur l'éthique et la religion (Paris: PUF, 2004), 74.

42 Ibidem.

43 Ibidem, 75.

44 Idem, O fenomenologii, 103. 
Tym sposobem objawianie się życia i to, co ono objawia, tworzą jedno"45. Proces samoobjawiania się życia jest więc zarazem procesem Pra-objawiania się Boga. Tożsamość Życia absolutnego i życia ludzkiego pozwala także twierdzić, iż jedyne miejsce przystępu do boskości to nasza cielesność (chair), w której manifestuje się życie. Przystęp do Boga jest więc możliwy tylko w taki sposób, w jaki życie ma dostęp do siebie, czyli w samoodczuwaniu się życia. Nie jest bowiem możliwe poznanie tego, co niewidzialne i nieobiektywizowalne, a więc Boga jako Życia absolutnego.

\section{Tajemnica obecności Boga: Marcel}

W filozofii Gabriela Marcela, z punktu widzenia tematyki badanej $\mathrm{w}$ artykule, kluczowe jest pojęcie tajemnicy, odróżnione przez filozofa od problemu. Ta ostatnia kategoria odpowiada przedmiotowości, gdyż, jak przedmiot, problem znajduje się „przede mną” i mogę nim zawsze manipulować dzięki wyuczonej technice, np. poznawczej. Tajemnica która może być wszak zredukowana do roli problemu, gdy jest czynnie negowana lub po prostu nieuznana - $\mathrm{w}$ istocie jednak nie poddaje się żadnej manipulacji. Niepoznawalność tajemnicy należy do jej istoty, ale zarazem jest ona pewną nieprzedmiotową obecnością, nie mającą nic wspólnego z obecnością poznawczą, o której pisze Husserl. Tajemnica jest obecnością par excellence, pozostającą w ścisłym związku z intersubiektywnie rozumianą wiecznością ${ }^{46}$. To ostatnie określenie Marcel odnosi do wspólnoty ontologicznej, która łączy ludzi wzajemnie ze sobą oraz z Bogiem i ściśle wiąże się z tajemnicą ontologiczną. Bowiem istotą intersubiektywności, niemal tożsamej z byciem, jest dla filozofa „obecność odczuwalnego podłoża, głęboko zakorzenionej w sferze ontologicznej wspólnoty, bez której rzeczywiste ludzkie więzi byłyby niezrozumiałe, albo, dokładniej rzecz biorąc, musiałyby być uznawane wyłącznie za twory wyobraźni”" ${ }^{\prime 7}$. Wspólnotę z innymi ludźmi określa wspólne bycie, ale, jak pisze Marcel, „troszczę się o byt tylko o tyle, o ile bardziej lub mniej wyraźnie uświadamiam sobie ukrytą jedność, łączącą mnie z innymi bytami, których rzeczywistość przeczuwam" ${ }^{48}$.

45 Ibidem, 213 (kursywa w tekście oryginalnym).

46 Gabriel Marcel, Tajemnica bytu, tłum. Małgorzata Frankiewicz (Kraków: Wyd. Znak 1995), 228.

47 Ibidem, 244.

48 Ibidem. 
Ontologia, oparta na relacjach międzyosobowych, wiąże się tu od razu $\mathrm{z}$ pojęciem Boga, o którym „nie można $\mathrm{w}$ rzeczywistości myśleć albo najwyżej można o nim myśleć jako o idolu, a nie jako o duchu"49, jeśli stosuje się ludzkie kategorie poznawcze, nawet takie jak pojęcie osoby. Bóg u Marcela jednak w pewnym sensie jest osobą, czyli osobowym Ty, do którego jako mieszkańcy skrajnie zobiektywizowanego, sfunkcjonalizowanego i stechnicyzowanego współczesnego świata, możemy modlić się z nadzieją na ocalenie. Bóg jest Ty absolutnym, do którego zwracam się jak do gwaranta „tej jedności, jaka łączy mnie ze mną samym lub jednego człowieka z drugim, bądź jednych z drugimi" ${ }^{50}$. Wraz z określeniem Boga mianem absolutnego Ty czy absolutnej Ucieczki, która jest fundamentem nadziei w sytuacji próby, pojawia się u Marcela radykalna odmowa uprzedmiotowienia boskości. Nie można nawet mówić „o Bogu”, wolno tylko mówić „do Boga”. Odmawiając obiektywizujących określeń boskości, myśliciel w miejsce poznania Boga wprowadza relację modlitwy czy prośby ${ }^{51}$.

Tylko modlitwa jest właściwym sposobem mówienia wobec Boga. „Modlitwa - pisał Marcel - to czynna odmowa pomyślenia Boga jako porządku, to pomyślenie go naprawdę jako Boga - jako czyste Ty" ${ }^{2}$. Pojęcie tajemnicy jest kluczowe, gdyż nie pozwala uprzedmiotowić Boga w myśleniu. Bowiem „Tajemnica jest (...) możliwa jedynie w porządku (...) $t y{ }^{\prime \prime 53}$. Inaczej jest z przedmiotem wykluczającym tajemnicę. Filozof opowiada się więc przeciw możliwości obiektywnego poznania boskości, zwłaszcza dowodzenia istnienia Boga. Według Marcela „jest absurdem wyobrażenie sobie, że jakiś osobnik może udowodnić istnienie Boga (...). To czego istnienia można dowieść, nie byłoby, nie mogłoby być Bogiem. Niemożliwość obiektywnego dowodu istnienia Boga, absurdalność takiego sposobu stawiania problemu religijnego: oto rzeczy niewątpliwe. (...) ustalanie, iż coś istnieje, oznacza identyfikację tego, odszukanie (...)" ${ }^{24}$. Żadna forma oglądu czy przedstawiania Boga nie jest właściwa, bo wszelkie myślenie „to sposób unaoczniania”, który nie może

49 Ibidem, 261.

50 Gabriel Marcel, Homo Viator. Wstęp do metafizyki nadziei, tłum. Piotr Lubicz (Warszawa: IW PAX 1984), 62.

51 Francuskie słowo prière, użyte w tekstach oryginalnych, oznacza zarówno modlitwę, jak i prośbę.

52 Gabriel Marcel, Dziennik metafizyczny, tłum. Ewa Wende (Warszawa: IW PAX 1987), 150.

53 Ibidem, 151.

54 Ibidem, 181. 
odnosić się do bytów osobowych ${ }^{55}$. Identyfikacja przez dowody na istnienie Boga kwestionuje sens modlitwy i miłość do Tego, kto nie może być traktowany jako metafizyczne To. O takim metafizycznym przedmiocie można wydawać sądy, ale nie odnoszą się one do Boga, absolutnego Świadka czy absolutnej Ucieczki, przychodzącej mi na ratunek w dramacie egzystencji ${ }^{56}$.

Relacja z Bogiem, którego nie wolno uprzedmiotawiać, dokonuje się w oparciu o uczestnictwo w tajemnicy ontologicznej. Partycypacja ta zakłada jednak istnienie wspólnoty, której ośrodkiem jest Bóg. Tajemnica, w tym kontekście, to „rodzaj płodnej nieokreśloności, gdzie byty obcują, gdzie są poprzez i dzięki samemu aktowi obcowania" ${ }^{\prime 7}$. Nie jest to jednak żadna całość czy magma, w której gubi się konkretna osobowość lub tożsamość uczestników tajemnicy ontologicznej. „Ta nieokreśloność - podkreśla Marcel - nieodróżnianie pomiędzy «ty» $\mathrm{i}$ «ja», pomiędzy «ty» $\mathrm{i}$ «on», nie jest elementem obojętnym, w którym powinniśmy się zagubić i jakby wyrzec się czegoś; jest to raczej rodzaj żywotnego środowiska duszy, z którego czerpie ona swą siłę, w którym odświeża się poprzez doznania" ${ }^{58}$. Uczestnictwo we wspólnocie ontologicznej, w przypadku człowieka, bywa ambiwalentne, gdyż ludzkie „ja” może stać się „on”, może więc być traktowane jak przedmiot. Inaczej jest w przypadku Boga, czyli „tam, gdzie «Ty» jest czymś absolutnym, to znaczy tam, gdzie [TY] z istoty swej wymyka się wszelkiemu obiektywnemu ujęciu, gdzie jest, nie powiem, dostępne, lecz obecne dla wezwania, czyli dla modlitwy (...)"59. Bóg „wymykający się” obiektywnym określeniom jest dostępny tylko dla człowieka, który zwraca się do Niego z prośbą zakładającą wspólnotę z innymi ludźmi, gdyż najczystszą modlitwą jest prośba o dobro dla innych, a dla siebie tylko o tyle, o ile to, o co proszę pozwoli mi bardziej być dla innych.

Uczestnictwo $\mathrm{w}$ tajemnicy to partycypacja $\mathrm{w}$ „niewyczerpanym konkrecie”, wejście w świat przekraczający doświadczenie ograniczane przez identyfikację czy problematyzację. Tajemnica wykracza poza każdy system wiedzy. Uczestnicząc w tajemnicy, jak pisze Marcel, „Jestem zaangażowany in concreto $\mathrm{w}$ porządku, który z samej definicji nigdy nie może stać się przedmiotem lub systemem dla mnie, lecz jedynie dla

55 Ibidem, 183.

56 Ibidem, 201-202.

57 Gabriel Marcel, Od sprzeciwu do wezwania, tłum. Stanisław Ławicki (Warszawa: IW PAX 1965), 51.

58 Ibidem.

59 Ibidem, 52. 
myśli, która mnie przewyższa, obejmuje i z którą nawet w sposób idealny nie mogę się utożsamić. Słowa: «ponad», «transcendencja» nabierają tu pełnego znaczenia" ${ }^{60}$. Transcendencja to właściwe dla naszego języka określenie istnienia Tego, Kto mnie przekracza, ale zarazem obejmuje i podtrzymuje, gdy uznaję sens tajemnicy bycia we wspólnocie z innymi. Tajemnica nie ma więc nic wspólnego ze statycznym, przedmiotowym bytem, gdyż jest to życie w relacjach międzyosobowych, określonych jako dramatyczne ${ }^{61}$. Pojęcie transcendencji, jak pisze Marcel, „da się pomyśleć jedynie na podstawie uczestniczenia w rzeczywistości, która mnie przepełnia i otacza, przy czym jednak w żaden sposób nie mogę traktować jej jako czegoś zewnętrznego, wobec tego kim jestem"62.

Bóg, którego mogę tylko wzywać w modlitwie (prośbie), ale nie poznawać, jest Tym, Kto odpowiada na wezwanie, którym jest już pytanie, które sobie zadaję: „kim jestem?”. „Transcendencja tego, kogo wzywam - podsumowuje Marcel - afirmuje się w stosunku do wszelkiego możliwego doświadczenia, a nawet $\mathrm{w}$ stosunku do wszelkich racjonalnych wyliczeń, będących zresztą tylko antycypowanym i uschematyzowanym doświadczeniem" ${ }^{3}$. Odpowiedzią na pytanie o tożsamość jest filozofia transcendencji, która, zdaniem filozofa, „zupełnie nie da się oddzielić (...) od refleksji dotyczącej hierarchii sposobów uwielbienia, przy czym refleksja ta znajduje zapewne wyraz nie tylko w teorii, lecz w uznaniu świętości, rozumianej nie jako sposób bycia, ale jako dana, oznaczająca najczystsze intencje. Tutaj i tylko tutaj zostaje przezwyciężone to, co problematyczne, a jednocześnie znika groźba śmierci, przechodząc w pełnię, która jest samym bytem" ${ }^{64}$. W ten sposób uzasadnia się „Zbieżność tego, co tajemnicze, z tym, co ontologiczne” ${ }^{65}$. Zdaniem Marcela bowiem „Zastanawiać się, jak mogę myśleć o Bogu, to poszukiwać, w jaki sposób mógłbym być razem $z$ Nim" ${ }^{66}$. Bóg może być mi dany wyłącznie w wielbieniu Go. W adoracji traktuję wszak Boga jako absolutną Obecność. Jeśli wytwarzam sobie o Nim pojęcie, to jest ono tylko abstrakcją, intelektualizacją nieprzedmiotowej Obecności. Samo używanie

\footnotetext{
60 Ibidem, 94.

61 Ibidem, 175.

62 Ibidem, 186.

63 Ibidem, 187.

64 Ibidem, 188.

65 Gabriel Marcel, Być i mieć, tłum. Donata Eska (Warszawa: IW PAX, 1998), 145.

66 Ibidem, 41.
} 
tych pojęć może stać się świętokradztwem, jeśli nie będę pamiętał, że są one dalekie od rzeczywistości, którą chcą uchwycićc7.

\section{Zakończenie}

Przeprowadzone analizy pokazują, że Marcel posługuje się pojęciem tajemnicy, która wykracza poza to, co światowe i co jest dostępne poznawczo, w kierunku tego, co boskie. Jest ona przeciwieństwem problemu, ale obejmuje też to, co światowe, gdy uwzględnia wspólnotę konkretnych relacji międzyosobowych. Jest ona tym, czego możemy doświadczać, chociaż doświadczenie nie polega tu na obiektywizacji. Kontekst analiz pozwala uczynić z tajemnicy kluczową kwestię wobec impasu zarysowującego się w myśli Lévinasa i Henry’ego, zwłaszcza gdy zostają one ze sobą zestawione. Wydaje się bowiem, że pojęcie tajemnicy relatywizuje radykalność transcendencji Boga, pojmowanej jako nieobecność, jak i zmniejsza niedostępność immanentnej boskości z fenomenologii życia. O ile stanowiska Lévinasa i Henry’ego narażają się na zarzut jednostronności, to Marcel wydaje się jej unikać, gdy w odniesieniu do Boga używa określenia tajemnicy. Jest tak, gdyż nie rezygnując z pojęcia transcendencji, nie nadaje mu tak radykalnego znaczenia, jak Lévinas. Jednak także Marcel nie dopuszcza opisu Boga w kategoriach przedmiotowych, które silą się na wyczerpanie tego, co boskie w ludzkich słowach ${ }^{68}$. Zarazem w pojęciu tajemnicy proponowanym przez tego autora zawiera się pewien sens immanencji Boga, tak względem podmiotu, jak i świata. Wiąże się to z uczestnictwem podmiotu we wspólnocie ontologicznej, której „Zwornikiem” jest Bóg, nadzieja zbawienia dla wszystkich ludzi. Jednak sama tajemnica nie daje się opisać lub wyczerpać ani za pomocą pojęcia transcendencji, ani dzięki odwołaniu się do immanencji Boga.

Tajemnica albo Bóg jako Tajemnica jest tym, co może być doświadczane przez człowieka, a więc co może być dostępne podmiotowi religijnemu (homo religiosus). Według Marcela bowiem istnieje doświadczenie transcendencji, które nie może zostać wchłonięte przez immanencję „rozbitego świata”, opartą na obiektywizacji, której Boga poddać nie można. Mamy tu więc opozycję wobec Lévinasa co do pojęcia doświadczenia. Dla tego ostatniego bowiem doświadczenie fenomenologiczne jest zredukowane do intencjonalności, zaś autor Homo viator wypracował ideę refleksji „wtórej” („odzyskującej”), przywracającej źródłowe

67 Ibidem, 249.

68 Idem, Od sprzeciwu do wezwania, 53: „Gdy mówimy o Bogu, to nie o Bogu mówimy”. 
doświadczenie sięgające pierwotnych, niepoddanych obiektywizacji warstw naszego bycia. Doświadczenie jest bowiem dla Marcela zawsze konkretne i zindywidualizowane, a jego najgłębszy poziom to uczestnictwo we wspólnocie ontologicznej, której spoiwem jest Bóg. Również u Lévinasa znajdujemy doświadczenie źródłowe w postaci transcendencji Twarzy i idei Nieskończoności, a u Henry’ego doświadczenie źródłowe pojęte jako samoodczuwanie absolutu Życia w immanencji subiektywnej cielesności (chair). Problematyczne jednak wydaje się, że Boga, który jest ukryty w radykalnej immanencji (Henry) lub tak transcendentny, że aż nieobecny (Lévinas) nie można doświadczyć jako absolutu zbawiającego nas od zła obecnego w dramacie egzystencji w „rozbitym świecie”. Na kwestię tę odpowiada jednak koncepcja tajemnicy ontologicznej z myśli Marcela.

Autorzy omówionych koncepcji rozumienie boskości wiążą z tym, co nie tylko wykracza poza ludzkie poznanie, lecz co z istoty jest niepoznawalne. Są to więc współczesne figury niewidzialności Boga. Jednak pojęcie tajemnicy nie tylko obejmuje sobą pojęcia transcendencji i immanencji, lecz umożliwia to, co dla tych jednostronnie używanych i często przeciwstawianych sobie pojęć było niemożliwe: uchronienie niewidzialnego Boga przed uprzedmiotowieniem, a zarazem umożliwia relację religijną, która jest praktycznie niemożliwa u Lévinasa i Henry’ego, jeśli rozumiemy tę relację w sposób biblijny ${ }^{69}$, opisany przez filozofów dialogu (np. Martin Buber), a który wydaje się najgłębszym opisem tej relacji ${ }^{70}$. U Lévinasa istnieje służba drugiemu człowiekowi, jednak religia staje się u niego etyką, gdzie Boga niejako zastępuje człowiek. Wedle Henry'ego natomiast dostęp do Boga mamy w samoodczuwającym się życiu naszej cielesności (chair). Bóg został jednak ostatecznie utożsamiony w tej myśli z ludzkim życiem i wydaje się niemożliwe, a przynajmniej bardzo trudne, uzyskanie dystansu wobec doświadczania życia

69 Chodzi o relację religijną rozumianą dialogicznie, jak ją przedstawia np. Jan Paweł II, Przekroczyć próg nadziei (Lublin: RW KUL, 1994), 46: „Całe życie ludzkie jest «współbytowaniem» $w$ wymiarze codziennym: «ty» $i$ «ja», a także $w$ wymiarze absolutnym $i$ ostatecznym: «ja» $i$ «Ty». Tradycja biblijna koncentruje się wokół tego «Ty». To jest naprzód Bóg Abrahama, Izaaka i Jakuba. Bóg Praojców, a z kolei Bóg Jezusa Chrystusa i Apostołów, Bóg naszej wiary”.

70 Relacja religijna została opisana w sposób biblijny najgłębiej jako dramat, m.in. w filozofii dialogu Marcela, ale też w fenomenologii dialogicznej Józefa Tischnera, Filozofia dramatu. Wprowadzenie (Paris: Éditions du Dialogue, 1990), 22: „właściwie istnieje tylko jeden dramat - dramat z Bogiem. Każdy inny dramat i inny wątek dramatyczny jest jedynie fragmentem tego dramatu. Jeśli tak, to ideałem dramatu w ogóle jest dramat religijny. Czy każdy dramat każdej religii? Nie, nie każdy - religią w pełnym sensie tego słowa dramatyczną jest jedynie judeochrześcijaństwo". 
w sposób czysto ludzki ${ }^{71}$. Dlatego wydaje się, że pojęcie tajemnicy z myśli Marcela lepiej spełnia wymogi stawiane przez Lévinasa pojęciu transcendencji, a przez Henry’ego pojęciu immanencji niż same te kategorie w odnośnych koncepcjach. Marcelowskie rozumienie tajemnicy pozwala bowiem uniknąć skrajności, w które wpada zarówno myślenie w kategoriach radykalnej transcendencji (Lévinas), jak i w kluczu absolutnej immanencji (Henry). W myśli Marcela, brak poznawczego dostępu do Boga zastępuje modlitwa, która nie jest w jakikolwiek sposób związana $\mathrm{z}$ obiektywizacją, lecz jest praktyczną relacją z partnerem dialogu, $\mathrm{z}$ absolutną Ucieczką, mającą zawsze osobowy charakter Ty absolutnego. O ile $\mathrm{w}$ dwu pierwszych koncepcjach następuje więc pewne zerwanie relacji między Bogiem a człowiekiem religijnym (homo religiosus), o którym mówi tradycja fenomenologii religii, ale także np. Martin Heidegger, to u Marcela biblijnie rozumiana relacja religijna jest zachowana.

O wartości przedstawionych koncepcji dla badań w fenomenologii religii stanowią więc konsekwencje, jakie wynikają z nich dla wizji Boga. Bowiem pytanie brzmi: czy obrazy Boga, kryjące się za figurami radykalnej transcendencji i absolutnej immanencji, są do przyjęcia dla człowieka religijnego, o którym możemy powiedzieć, uznając racje Heideggera, że człowiek ten chce się modlić do Boga i tańczyć przed nim² ${ }^{72}$. Inaczej mówiąc, kluczowe jest zagadnienie, czy Bóg tak transcendentny, że aż nieobecny (Lévinas), lub tak immanentny, że niedostrzegalny (Henry), może pretendować do bycia Bogiem jakiejkolwiek religii, zwłaszcza związanej z tradycją judeochrześcijańską? Czy jednak, w związku z negatywną odpowiedzią na to pytanie, nie należy myśleć o Bogu, jak czyni to Marcel, zarówno w sposób prowadzący do uniknięcia idolatrii poznawczej, jak i w kategoriach nieprzedmiotowej obecności. Wydaje się, że tylko ten sposób ujęcia Boga pozwala homo religiosus wejść w pewną konkretną relację z boskością.

71 W fenomenologii życia relacja z Bogiem jako Życiem absolutnym jest ostatecznie pojęta w ten sposób, że w życiu codziennym nie można odróżnić relacji religijnej od relacji z naszym własnym życiem, o czym dobrze wie twórca fenomenologii życia. Michel Henry, „Sztuka i fenomenologia życia”, tłum. Monika Murawska w Przegląd Filozoficzno-Literacki 3(34) (2012): 172.

72 Martin Heidegger, „Onto-teo-logiczny charakter metafizyki”, tłum. Janusz Mizera, Principia, t. XX (1998): 182. 


\section{Bibliografia}

Biemel Walter, „L'idée de la phénoménologie chez Husserl”, w Phénoménologie et métaphysique, red. Jean-Luc Marion i Guy Planty-Bonjour (Paris: Presses Universitaires de France, 1984), 81-104.

Greisch Jean, Le buisson ardent et les lumières de la raison : L'invention de la philosophie de la religion, t. II: Les approches phénoménologique et analytiques (Paris: Cerf, 2002).

Heidegger Martin, „Onto-teo-logiczny charakter metafizyki”, tłum. Janusz Mizera, Principia, t. XX (1998): 165-184.

Henry Michel, C'est Moi la Vérité. Pour une philosophie du christianisme (Paris: Seuil, 1996).

Henry Michel, Lessence de la manifestation (Paris: Presses Universitaires de France, 2003).

Henry Michel, Phénoménologie de la vie, t. IV: Sur l'éthique et la religion (Paris: Presses Universitaires de France, 2004).

Henry Michel, Entretiens (Cabris: Sulliver, 2007).

Henry Michel, O fenomenologii, tłum. M. Drwięga (Warszawa: Wyd. IFiS PAN, 2007).

Henry Michel, „Sztuka i fenomenologia życia”, tłum. Monika Murawska, Przegląd Filozoficzno-Literacki 3/34 (2012): 156-179.

Henry Michel, Wcielenie. Filozofia ciała, tłum. Dariusz Adamski, Małgorzata Frankiewicz (Kraków: Homini, 2012).

Jan Paweł II, Przekroczyć próg nadziei (Lublin: Redakcja Wydawnictw Katolickiego Uniwersytetu w Lublinie, 1994).

Lévinas Emmanuel, O Bogu, który nawiedza myśl, tłum. Małgorzata Kowalska (Kraków: Wyd. Znak, 1994).

Lévinas Emmanuel, Imiona własne, tłum. Janusz Margański (Warszawa: Wyd. KR, 2000).

Lévinas Emmanuel, Bóg, śmierć i czas, tłum. Janusz Margański (Kraków: Wyd. Znak, 2008).

Marcel Gabriel, Od sprzeciwu do wezwania, tłum. Stanisław Ławicki (Warszawa: Instytut Wydawniczy PAX, 1965).

Marcel Gabriel, Homo Viator. Wstęp do metafizyki nadziei, tłum. Piotr Lubicz (Warszawa: Instytut Wydawniczy PAX, 1984).

Marcel Gabriel, Dziennik metafizyczny, tłum. Ewa Wende (Warszawa: Instytut Wydawniczy PAX, 1987).

Marcel Gabriel, Być i mieć, tłum. Donata Eska (Warszawa: Instytut Wydawniczy PAX, 1998).

Marcel Gabriel, Tajemnica bytu, tłum. Małgorzata Frankiewicz (Kraków: Wyd. Znak, 1995).

Perkowska Halina, Bóg filozofów XX wieku. Wybrane koncepcje (WarszawaPoznań: Wydawnictwo Naukowe PWN, 2001).

Płotka Witold, Fenomenologia jako filozofia mniejsza. Rozważania wokół sporów o metodę Husserla (Warszawa: Liberlibri, 2019). 
Schaeffler Richard, Filozofia religii, tłum. Elżbieta Kowalska (Częstochowa: Częstochowskie Wydawnictwo Diecezjalne Regina Poloniae, 1989).

Souche-Dagues Denise, Le développement de l'intentionnalité dans la phénoménologie husserlienne (Paris: Vrin, 1993).

Tarnowski Karol, Bóg fenomenologów (Tarnów: Biblos, 2000).

Tarnowski Karol, „Intencja a refleksja. Fenomenologia, Nabert, Marcel”, w: Między przedmiotowościq a podmiotowościa: intencjonalność $w$ fenomenologii francuskiej / Entre l'objectivité et la subjectivité: l'intentionnalité dans la phénoménologie française, red. Andrzej Gielarowski, Robert Grzywacz (Kraków: Akademia Ignatianum-Wydawnictwo WAM, 2011), 19-34.

Tischner Józef, Filozofia dramatu. Wprowadzenie (Paris: Éditions du Dialogue, 1990).

Van der Leeuw Gerardus, Fenomenologia religii, tłum. Jerzy Prokopiuk (Warszawa: Książka i Wiedza, 1997). 
